\title{
Effect of Micro-teaching Practices with Concrete Models on Pre-service Mathematics Teachers' Self-efficacy Beliefs about Using Concrete Models
}

\author{
Melihan Ünlü \\ Faculty of Education, Aksaray University, Aksaray, 68100, Turkey
}

Copyright $\subset 2018$ by authors, all rights reserved. Authors agree that this article remains permanently open access under the terms of the Creative Commons Attribution License 4.0 International License

\begin{abstract}
The purpose of the current study was to investigate the effect of micro-teaching practices with concrete models on the pre-service teachers' self-efficacy beliefs about using concrete models and to determine the opinions of the pre-service teachers about this issue. In the current study, one of the mixed methods, the convergent design (embedded) was used. The participants in the study consisted of 41 pre-service elementary mathematics teachers who were enrolled mathematics teacher education programme at a state university in Turkey. In this research, The Instrument of Pre-service Mathematics Teachers Efficacy Beliefs about Using Concrete Models developed by Bakkaloğlu [44] and interview forms were used as data collection tools. The research revealed that the micro-teaching practices with concrete models had positive effects on the pre-service teachers' self-efficacy beliefs about using concrete models. Pre-service teachers think that these micro-teaching practices had positive effects on the skills of teaching.
\end{abstract}

Keywords Concrete Models, Micro-teaching, Self-efficacy Beliefs, Pre-service Mathematics Teachers

\section{Introduction}

In the changing world, those who understand and do mathematics will be more successful in the future [1]. It is thought that each student can learn mathematics, but direct perception of abstract mathematical concepts is considerably difficult. It is therefore important to provide students with learning environments conducive to conceptual and meaningful learning rather than to recall and recognition of information [2]. In particular, younger students will learn mathematics more meaningfully in learning environments where information is represented by concrete models. According to educational research, the most valuable learning occurs when students actively construct their own mathematical understanding by using concrete models [3]. This showed how important and necessary is the use of concrete and finite life models in teaching mathematical concepts [2].

Concrete models used in mathematics teaching have many contributions to teaching and learning. Concrete models embody abstract mathematical concepts [4,5], facilitate the understanding of mathematical concepts [5-9], make conceptual learning possible [10], increase retention $[9,11,12]$, contribute to the development of positive attitudes in students [13-16] and provide exploratory opportunities for students to solve problems [17]. Over the past few decades, researchers have studied the use of concrete models in several different grade levels. Many studies have shown that concrete models help teaching and enhance the quality of education and achievement $[3,16$, 18-24]. As a result of his meta-analysis of 60 studies, Sowell [16] argued that long-time use of concrete models can increase mathematics achievement and the instruction delivered by teachers knowledgeable about the use of concrete models improve students' attitudes towards mathematics.

On the other hand, some studies show that the use of concrete models does not always have an effect on performance and does not always guarantee success [25]. Most of the time materials on their own cannot be effective on the learning of concepts $[5,19,26]$. This indicates that the effective use of concrete models in teaching depends on teachers [16]. Marshall and Swan [27] stated that teachers play an important role in structuring when and how math concrete models are used to support learning. Kelly [17] also noted that for the effective use of concrete models, teachers need to know when, why, and how to use concrete models.

Moyer [5] stated that even though teachers have the skills necessary for the effective use of concrete models, their beliefs about how learners can learn mathematics are 
effective in their use of concrete models. On the other hand, self-efficacy beliefs possessed by teachers about using concrete models also influence the use of concrete models in their classes [29]. Teachers with low self-efficacy beliefs have been found to avoid challenging activities and materials while teachers with high self-efficacy beliefs can construct a positive classroom environment [30] and be more persistent in removing the obstacles they have encountered in the teaching process [31,32]. Teachers with high self-efficacy beliefs about using concrete models will invest more effort to overcome the difficulties they face during the course of using concrete models in their lessons. However, a teacher who is not competent in using concrete models cannot be expected to use concrete models in his/her classes and to have high self-efficacy beliefs about using concrete models because it is not easy for teachers and pre-service teachers having limited experiences about this issue to acquire the skills necessary to select appropriate concrete models and use these concrete models effectively in their classes [33]. Çakıroğlu and Yıldız [34] argued that teachers who use materials during their undergraduate education will be more willing to use materials when they become teachers. In this regard, construction of learning environments where the skills of using concrete models can be acquired by pre-service teachers is important.

In the inculcation of skills necessary for the use of concrete models in mathematics classes in pre-service teacher, micro-teaching technique is believed to prove quite effective because the micro-teaching technique is widely used to impart the skills required for effective teaching to pre-service teachers and to prepare them for the profession of teaching [35]. Through the micro-teaching technique, settings smaller than the actual settings in terms of class size and class hour are created and in this setting practicum, teaching is performed. Thus, connections between theory and practice can be established. In micro-teaching applications, pre-service teachers are provided with opportunities to do practice in front of their peers within a short period of a class hour (5 to 20 minutes). Recording of the micro-teaching process allows pre-service teachers to conduct self-evaluation after the lesson [36]. In this regard, it is believed that as a result of the delivery of instruction about a mathematics subject in the elementary school mathematics curriculum by pre-service teachers by using concrete models through the micro-teaching technique will result in changes in their self-efficacy beliefs about the use of concrete models. When the literature was reviewed, no study was encountered focusing on the effect of micro-teaching practices conducted by using concrete models on pre-service mathematics teachers' self-efficacy beliefs and skills for using concrete models in math classes. In addition, this current research is also of great importance in the sense that it is a research where concrete models and micro-teaching techniques are used together to give pre-service teachers opportunities to apply concrete models. Therefore, the study is believed to help fill this void in the literature. In the study, the pre-service teachers will be provided with opportunities to apply theoretical information and moreover, how they delivered their lessons in the classroom environment will be watched and feedbacks about the skill of using concrete models that is a skill to be imparted to pre-service teachers will be given to them. In this regard, the purpose of the current study is to investigate the effect of micro-teaching practices on the pre-service teachers' self-efficacy beliefs about using concrete models in mathematics classes and to determine the opinions of the pre-service teachers about this issue.

\subsection{Concrete Models}

Sowell [16] classified manipulatives materials as concrete, pictorial, and abstract or symbolic. Concrete materials refer to materials that can be used and carried by students such as geometry board, beans and rods. Pictorial manipulatives are materials including visuals such as pictures, diagrams and graphics or animated images such as videos. Abstract or symbolic manipulatives are tools and equipment such as books, worksheets and pencils used by students while studying at school. Concrete models are comprised of math tools and equipment and real life objects used to embody abstract mathematical concepts [5, 38]. They can be touched and carried by students so they provide tangible exploratory experiences for abstract mathematical concepts [39]. Objects used in daily life such as beads, beans and measurement tools or objects specially designed to be used in math instruction such as based ten blocks, geometry board and pattern blocks can be used as concrete models [33]. In elementary school mathematics curriculums, instructional tools and equipment such as geometry board, geometry strips, based ten blocks, symmetry mirror, volumes set, geometry pieces, tangrams, pattern blocks, fraction cards, fraction bars, unit cubes, algebra tiles, multi-squares set, multi-cubes set, geometric objects are defined as concrete models [2].

Ball [19, p. 16] emphasized that manipulatives, concrete models are very important for the improvement of mathematics learning, because a manipulative mathematics has a potential of contributing to the recognition and development of math-related concepts and ideas [24]. They establish connections between mathematical concepts and everyday experiences [40]. In addition, The NCTM's Curriculum and Evaluation Standards [41, p.87] also stated that "Mathematics learning should be grounded the use of concrete models designed to reflect underlying mathematical ideas and concepts."

If concrete models are used correctly, they can be extremely helpful for young students [3]. For that reason, teachers need to be aware of how they are using concrete models in their teaching [42] and manage the learning environment to support the development of mathematical 
concepts [27]. Yetkin-Özdemir [33] indicated that even though pre-service teachers have positive attitudes towards using concrete models, they do not have a clear idea about how concrete models help students understanding mathematical concepts and they often encounter difficulties in guiding students to establish connections between mathematical concepts and concrete models. Kamina-Iyer [43] also stated that pre-service teachers had difficulty in transferring knowledge from enactive concrete models to mathematics symbols and abstraction. For that reasons it is important for pre-service teachers to gain skills of using concrete models.

In addition, teachers' judgment about themselves to be effective in using materials in their teaching is another important issue regarding the teachers' concrete models uses [44]. Teachers incompetent in the use of mathematics concrete models invest less effort for continuing the use of materials [16].

\subsection{Self-efficacy beliefs towards Concrete Models}

Self-efficacy belief is defined as "an individual's judgement of their capacity to organize the activities required for a certain performance, and to achieve it" [45]. On the other hand Bakkaloğlu [44] defined self-efficacy beliefs about using concrete models in teaching as "their judgments about themselves to be effective in utilizing these materials in their teaching". Pişkin [29] investigated that the instruction based on using concrete models had positive contributions on the pre-service elementary mathematics teachers' self-efficacy beliefs and outcome expectancies about using concrete models in teaching mathematics. Pre-service teachers believed that using concrete models in teaching mathematics would have positive consequences in teaching process and students' learning. However, when the concrete models were involved in the instruction, they had relatively low personal efficacies and outcome expectancies about classroom management. On the other hand, Aydoğdu-İskenderoğlu, Türk and İskenderoğlu [46] indicated that pre-service teachers deemed themselves efficient in terms of the use of concrete materials in mathematics education. They could recognize concrete materials usually, but they usually failed to use materials.

Sources of self-efficacy beliefs are mastery experiences, vicarious experiences, social persuasions, and psychological states. The most effective of these self-efficacy sources is mastery experiences. Students, who have successful past experiences, have a strong self-efficacy belief, while other students, who experience failure before forming a strong self-efficacy belief, develop a negative self-efficacy belief [47]. One important source of self-efficacy beliefs is indirect experiences, that is, individuals constantly observe their parents, teachers, siblings and peers in their daily lives that they consider important to them, and these observations affect the students' self-efficacy beliefs. Another source of self-efficacy is verbal and social persuasion. The development of people's self-efficacy can be influenced by encouraging words from parents, teachers or friends. Encouraging verbal expressions and positive feedback from teachers and parents can increase students' self-efficacy beliefs. One of the sources of self-efficacy is the emotional and psychological states. As the individual's feeling spiritually and physically well increases the probability of fulfilling a given task, the physical and emotional state of a person is influential in the formation of judgments about his/her abilities. Thus, individuals having high levels of anxiety and stress may have a low self-efficacy belief [30, 48, 49]. Direct experiences are one of the important sources nurturing self-efficacy beliefs. Thus, it is believed that pre-service teachers' self-efficacy beliefs about using concrete models can be changed by exposing them into direct experiences. One of these applications is the micro-teaching technique. Because positive feedbacks provided through video-recordings, teacher trainer and peer commentaries on the performance of a pre-service teacher can enhance his/her self-efficacy beliefs.

\subsection{Micro-teaching Practices}

The micro-teaching technique, one of the techniques used to impart the skills that need to be acquired by pre-service teachers to them $[35,51,52]$, was first introduced in 1960 by Dwight W. Allen and his colleagues at Stanford University. The micro-teaching technique used to prepare pre-service teachers for the profession is also very effective in establishing the relationship between theory and practice. Through micro-teaching practices, environments where pre-service teachers can be engaged in teaching practices can be created. These environments are usually smaller in terms of class size and time than actual environments [52]. In a micro-teaching application, the pre-service teacher is given time ranging from 5 to 20 minutes to deliver his/her lesson. These environments provide pre-service teachers with opportunities to do some practice in front of their peers [36]. The micro-teaching process works in the following way: The pre-service teacher delivering the lesson is observed by his/her instructor and peers and this process is video-recorded. Then this video is watched in the classroom environment and evaluated in terms of the competencies to be acquired by pre-service teachers. In line with the given feedbacks, the pre-service teacher revises his/her lesson plan and delivers his/her lesson again and the lesson is evaluated once more to determine the points at which the pre-service teacher is successful or unsuccessful $[35,53]$. The results of this evaluation are shared with the pre-service teacher; thus, the performance evaluation is completed [52, 54]. It is important for the instructor not to interrupt the lesson and to give feedback at the end of the lesson [52]; yet, due to 
crowded classes and lack of time not enough feedback can be given to each pre-service teacher [55]. However, it has been reported that micro-teaching practices develops skills of classroom management, activity and materials design, board use and time management [56]. Peker [57] stated that micro-teaching practices contributed to the development of pre-service teachers in terms of planning, timing, giving various examples, asking questions, classroom management, materials use and physical appearance.

Today, micro-teaching practices are widely used in teacher education research [52, 55, 58-60] and in many studies, it has been concluded that they have positive effects on instructional skills [35, 61-64]. Kılıç [62] investigated the effect of Learner-Centered Micro-Teaching on the development of pre-service teachers' teaching competencies. According to the results, Learner-Centered Micro-Teaching had a progress in pre-service teachers' teaching behaviors on subject area, planning, teaching process, classroom management, communication, and evaluation. Moreover, there are some studies demonstrating the positive influences of micro-teaching practices on self-efficacy beliefs [50, 65-69]. In the light of these researches, this study investigates the effect of micro-teaching practices on the pre-service teachers' self-efficacy beliefs about using concrete models in mathematics classes and determines the opinions of the pre-service teachers about this issue.

\section{Methods}

\subsection{Research Design}

The current study aims to investigate the effect of the micro-teaching technique on the pre-service mathematics teachers' self-efficacy beliefs about using concrete models in mathematics classes employed the mixed method in which qualitative and quantitative research methods are used together. In the current study, one of the mixed methods, the convergent design (embedded) was used. The purpose of the convergent design is to collect different but complementary data on the same subject. Depending of the interest of the research, it collects both qualitative and quantitative data. The collection of quantitative and qualitative data is simultaneously but separately performed. The analysis of the collected data is also performed independently. When the results are obtained, they are combined and in the last stage, the researcher interprets the results in terms of their similarities and differences [70].

In the quantitative part of the study, the pretest-posttest single group research design was used. The Instrument of Pre-service Mathematics Teachers Efficacy Beliefs about Using Concrete Models was administered as pre-test and post-test. In the qualitative part of the study, the pre-service teachers' opinions about the conducted micro-teaching practices by using concrete models were elicited for an in-depth inquiry of them.

\subsection{Participants}

The participants in the study consisted of 41 pre-service elementary mathematics teachers taking the Instructional Technologies and Material Design course while studying mathematics teacher education program at a state university in Turkey. The pre-service elementary mathematics teachers who participated in the study consisted of 6 men and 35 women between the ages of 19 and 24. The participants of the study were given names such as $\mathrm{S}_{1}, \mathrm{~S}_{2}, \mathrm{~S}_{3}, \ldots, \mathrm{S}_{41}$.

Instructional Technologies and Material Design is a course given in the $4^{\text {th }}$ semester of the elementary mathematics teacher education program. In the course of Instructional Technologies and Materials Design, instructional technologies used in teaching mathematics and what concrete materials are taught and pre-service mathematics teachers are expected to design a concrete material that can be used in mathematics education. It was purposefully chosen for this study because of its content.

\subsection{Data Collection Tools}

The Instrument of Pre-service Mathematics Teachers Efficacy Beliefs about Using Concrete Models: In the current study, The Instrument of Pre-service Mathematics Teachers Efficacy Beliefs about Using Concrete Models adopted by Bakkaloğlu [44] for pre-service mathematics teachers was employed to collect data. The scale consists of 15 items in the form of 5-point Likert item and two sub-dimensions. These two sub-dimensions are personal self-efficacy beliefs and outcome expectancies. Bakkaloğlu [44] calculated the Cronbach alpha value as 0.81 for the personal self-efficacy beliefs sub-dimension and 0.79 for the outcome expectancies sub-dimension. In this research Cronbach alpha is calculated as 0.83 .

Interview Forms: An interview form consisting of open-ended questions was used to elicit the pre-service teachers' opinions about the micro-teaching practices conducted by using concrete models. The interview form consisting of standardized open-ended questions was developed on the basis of a literature review made in line with the purpose of the study and submitted to the scrutiny of experts. In line with the feedbacks of the experts, required corrections were done on the form. The interview questions asked to the pre-service teachers are as follows:

1. Did the micro-teaching practices conducted with concrete models have any impact on your self-efficacy beliefs for using concrete models? 
2. What do you think about the use of concrete models in elementary school mathematics classes?

3. Did the micro-teaching practices conducted with concrete models have any impact on your skills of using concrete models?

4. Did the micro-teaching practices you conducted have some contributions to your teaching skills? How?

\subsection{Data Collection}

The applications were conducted for six class hours a week two of which were theoretical and four of which were practical. In the theoretical classes, theoretical information was given about information technology and materials. Moreover, the concrete models that could be used in mathematics education by the pre-service teachers were introduced by the researchers and instruction was given about how to use them in elementary school classes. Before and after the instruction, The Instrument of Preservice Mathematics Teachers Efficacy Beliefs about Using Concrete Models was administered to the pre-service teachers to measure their self-efficacy beliefs about using concrete models. As concrete models, geometry board, geometry strip, based ten blocks, fraction cards, fraction sets, unit cubes, algebra tiles were used. At the end of the instruction, each pre-service teacher was asked to conduct a micro-teaching practice in the class with one of the concrete models they selected. For this purpose pre-service teachers were asked to randomly select from among the acquisitions determined considering the content of the elementary school mathematics curriculum 5-8 in Turkey and then to design activities to contribute to the accomplishment of the selected acquisition by using concrete models. The micro-teaching practices done in the class was video-recorded, and after the presentation, the recordings were watched and then the opinions and criticisms of the pre-service teacher himself/herself, his/her instructor and peers were taken. Moreover, the pre-service teachers were asked to watch their own videos and to perform self-evaluation. Considering all these evaluations, a new lesson planning was made and then micro-teaching was conducted once more according to this new plan. After this second presentation, again feedbacks were given to the pre-service teachers. Following all these, the pre-service teachers' opinions about the micro-teaching practices were received through the interview form.

\subsection{Data Analysis}

In the current study, dependent samples t-test was used to compare the pretest and posttest scores of the pre-service teachers taken from the Self-efficacy Scale for the Use of Concrete Models. The collected data were analyzed in SPSS program package. In the analysis of the data collected through the interview form consisting of open-ended questions, the content analysis method was used. Within the content analysis, raw data similar to each other are brought together around certain themes and sub-themes in a comprehensible manner and then interpreted [71-72]. In this regard, separate data analysis was conducted for each data. Prior to the analysis of the collected data, the participants were numerated and then the responses were coded one by one. Afterwards, the themes obtained from a pre-school teacher were compared with those of the other pre-service teachers to come up with common themes. While conducting data analysis, it was seen that some participants gave responses including more than one theme. As each of the statements refers to a different meaning, such responses of the participants were included some different themes.

In order to establish validity and reliability in the current study, the data obtained from the pre-service teachers' responses given to the open-ended questions were analyzed and then sorted out and categorized by different researchers individually and independently. Then these sets of categories were compared with each other and their final form was given. The themes and sub-themes constructed in the content analysis were tabulated and their frequencies (f) and \% values are presented. Direct quotations were made from the pre-service teachers' statements and presented to readers. In both of the coding following the coding process, the issues on which there were "agreements" and "disagreements" were discussed and the required corrections were made.

All these operations conducted in the data analysis process were performed by two researchers separately. After each coding, the issues on which the researchers "agreed" and "disagreed" were discussed and then the required amendments were made. In order to calculate the reliability of the research, the reliability formula $($ Reliability $=$ Agreement/ (Agreement + Disagreement $)$ proposed by Miles and Huberman (1994) was used. When the reliability is found to be higher than $70 \%$, then it is considered to be acceptable (Miles and Huberman, 1994). In the current study, the reliability was calculated to be $91 \%$ for the first research question, $94 \%$ for the second research question and $90 \%$ for the third research question and $92 \%$ for the forth question.

\section{Results}

\subsection{Findings related to Qualitative Data}

3.1.1. The Effect of Micro-teaching Practices with Concrete Models on Self-efficacy Beliefs about Using Concrete Models

In order to investigate the effect of micro-teaching practices with concrete models on the pre-service teachers' self-efficacy beliefs about using concrete models, 
pretest-posttest single group research design was used. The results of the dependent samples t-test run to see whether there is a statistically significant difference between the pre-service teachers' pre-test self-efficacy beliefs mean score and post-test self-efficacy beliefs mean score about using concrete models are given in Table 1.

Table 1. Dependent t-test Results related to Self-efficacy Scale about Using Concrete models

\begin{tabular}{|c|c|c|c|c|c|c|}
\hline Group & $\mathrm{N}$ & $\bar{X}$ & $\mathrm{sd}$ & $\mathrm{df}$ & $\mathrm{t}$ & $\mathrm{p}$ \\
\hline Pre-test & 41 & 3.55 & 0.41 & \multirow{2}{*}{40} & -2.02 & 0.04 \\
\hline Post-test & 41 & 3.70 & 0.27 & & & \\
\hline
\end{tabular}

While the mean score taken from the Self-efficacy Scale for the Use of Concrete Models was $\bar{X}=3.55$ before the experimental treatment, it became $\bar{X}=3.70$ after the experimental treatment $(\mathrm{t}(40)=-2.02, \mathrm{p}<0.05)$. On the basis of this finding, it can be argued that the experimental treatment significantly increased the pre-service teachers' self-efficacy beliefs about using concrete models.

\subsection{Findings Related to Qualitative Data}

\subsubsection{Pre-service Teachers' Opinions about the Effect of} Micro-teaching Practices with Concrete Models on Self-efficacy Beliefs about Using Concrete Models

The pre-service teachers were asked the question "Did the micro-teaching practices conducted with concrete models have any impact on your self-efficacy beliefs about using concrete models?" While $85.37 \%(\mathrm{f}=35)$ of the pre-service teachers are of the opinion that the micro-teaching practices with concrete models had positive effects on their self-efficacy beliefs about using concrete models, $14.63 \%(\mathrm{f}=6)$ think that it did not have any positive effects or had some negative effects on their self-efficacy beliefs about using concrete models. In this regard, opinions of some pre-service teachers think that the micro-teaching practices conducted with concrete models have positive effects on their self-efficacy about using concrete models were given below:
With her statement "The micro-teaching practices conducted with concrete models have positive effects on my self-efficacy beliefs because I realized that I learned how to use concrete models, how to manage classroom by using concrete models, how to teach subjects with them and that I can cope with many problems in the classroom.", $\mathrm{S}_{25}$ indicated the positive effects of micro-teaching practices on their self-efficacy beliefs about using concrete models. On the other hand $\mathrm{S}_{21}$ mentioned that "...At first I thought that it would be difficult to teach by using concrete models yet once you have lived the experience of using them, I have been convinced that I can use them." and $\mathrm{S}_{37}$ stated that "Because with more practice with concrete models, I believe that I will be able to use them more competently and enhance my self-efficacy."

When the pre-service teachers' opinions were examined, it was found that some of them are of the opinion that the micro-teaching practices conducted with concrete models did not have any positive effects on their self-efficacy beliefs about using concrete models. One of these six pre-service teachers is $\mathrm{S}_{13}$ and she expressed her opinion as follows: "I have learned how to use these concrete models and how to adapt them to my lessons. I suppose that I can teach by using concrete models but in an actual classroom environment, I am not sure whether I will be able to manage the classroom effectively. Therefore, I do not feel much competent." and other pre-service teacher $\mathrm{S}_{5}$ indicated that "I thought that I would be able to teach many subjects by using concrete models. During the micro-teaching practices however, I realized that it would not be so. I do not see myself competent enough to use concrete models in teaching of each subject."

\subsubsection{Pre-service Teachers Opinions about the Use of Concrete Models in Elementary School Mathematics Classes}

The pre-service teachers were asked the question "What do you think about the use of concrete models in elementary school mathematics classes?" The findings obtained from the analysis of the pre-service teachers' responses to the question were presented in Table 2 . 
Table 2. Opinions about the Use of Concrete Models in Mathematics Classes

\begin{tabular}{|c|c|c|c|}
\hline & Theme & Sub-theme & $\mathrm{f}$ \\
\hline \multirow{11}{*}{ Materials should be used } & \multirow{8}{*}{ Academic dimension } & Permanent learning & 15 \\
\hline & & Reifying abstract concepts & 14 \\
\hline & & Facilitating learning, understanding & 13 \\
\hline & & Allowing visualization & 5 \\
\hline & & Conceptual learning & 4 \\
\hline & & Visualization in the mind/spatial thinking & 3 \\
\hline & & Effective teaching & 3 \\
\hline & & Reinforcing subjects & 2 \\
\hline & \multirow{2}{*}{ Affective dimension } & Drawing interest/attention & 7 \\
\hline & & Making the class more enjoyable & 3 \\
\hline & Time management dimension & Effective use of time & 4 \\
\hline \multirow{11}{*}{$\begin{array}{l}\text { Materials should not be } \\
\text { used }\end{array}$} & \multirow{2}{*}{$\begin{array}{c}\text { Challenges arising from class/time } \\
\text { management }\end{array}$} & Time consuming & 8 \\
\hline & & Making classroom management more difficult & 7 \\
\hline & \multirow{3}{*}{ Problems encountered in practice } & Crowded classes & 5 \\
\hline & & Becoming ordinary over time & 3 \\
\hline & & Prevention of imagination and thinking & 2 \\
\hline & \multirow{3}{*}{ Student perceptions } & Making students more confused & 5 \\
\hline & & Distracting attention & 4 \\
\hline & & Perceived as a game & 2 \\
\hline & \multirow{3}{*}{$\begin{array}{l}\text { Challenges arising from the } \\
\text { curriculum and system }\end{array}$} & Intensity of the curriculum & 2 \\
\hline & & Examination system & 2 \\
\hline & & Teaching through traditional ways is easier & 2 \\
\hline \multirow{6}{*}{ Sometimes } & \multirow{2}{*}{ Features of class and subjects } & In challenging subjects & 7 \\
\hline & & In some/suitable subjects & 3 \\
\hline & \multirow{4}{*}{ Costs and physical adequacy } & When physical conditions are adequate & 3 \\
\hline & & When the classroom is not crowded & 3 \\
\hline & & When concrete models are in sufficient number & 2 \\
\hline & & If cost is reduced & 2 \\
\hline
\end{tabular}

The opinions of the pre-service teachers thinking that concrete models should be used in elementary schools are addressed under three headings that are academic dimension, affective dimension and time management dimension. Under the academic dimension, they talked about the contribution of concrete models to teaching and learning such as permanent learning, reifying abstract concepts, facilitating learning and understanding, allowing visualization, conceptual learning, visualization in the mind/spatial thinking, effective teaching and reinforcing subjects. In this regard, $\mathrm{S}_{1}$ expressed her opinion as follows: "The course students have the greatest difficulty is math. Reifying an abstract subject and using concrete models for students' learning are advantageous." and $\mathrm{S}_{17}$ stated that "It embodies many concepts. For example, we can show that the area of a rectangle is calculated as a.b by using $a$ geometry board." Another pre-service teacher $\mathrm{S}_{11}$ explained her opinions as follows: "As students are young, only verbal expressions may not draw their attention. Therefore, use of concrete models is of great importance because in this way, the student is exposed to information by involving his/her visual, sensory and cognitive perceptions and thus learning becomes easier and more permanent." and $\mathrm{S}_{28}$ emphasized the importance of visualization in mind by saying "Concrete models enable students to visualize subjects in their minds."

Some pre-service teachers mentioned that concrete models' contribution to the affective dimension. In this dimension, they talked about how concrete models could be used to increase students' interest and attention and to make the lesson more enjoyable. For example, $\mathrm{S}_{3}$ stated that "In my opinion, concrete models should be used to make a lesson more enjoyable and to enhance the retention of information to be taught."

Moreover, some pre-service teachers mentioned the time management dimension by arguing that concrete models contribute to the effective use of time. For instance, $\mathrm{S}_{8}$ emphasized that "The use of concrete models enhances the efficiency of the lesson and enables better management of time."

Some pre-service teachers emphasized the difficulties involved in the use of concrete models in elementary schools due to their some adversities. The pre-service teachers' opinions about the negative sides of the use of 
concrete models are addressed under five different headings as negative sides resulting from classroom/time management, problems encountered in practice, student perceptions and challenges arising from the curriculum and system. The pre-service teachers mentioned variables such as concrete models leading to loss of time and making classroom management more difficult under the dimension of classroom/time management. With the statement of, "Teaching a class by using concrete models causes both loss of time and confuses students. If we conduct activities by using concrete models with students, everything can be confusing.", $\mathrm{S}_{5}$ emphasized classroom/time management.

The pre-service teachers mentioned crowded classes, their becoming monotonous over time and prevention of imagination and thinking as the problems seen under the dimension of problems encountered in practice. For instance, with her statements "Following the same way of presenting concrete models makes the lesson monotonous and it is quite difficult to teach in crowded classes by using concrete models." $\mathrm{S}_{31}$ indicated that using concrete models become monotonous over time and it is difficult to use in crowded classes. Moreover, a pre-service teacher is of the opinion that concrete models should not be used as they hinder imagination and thinking. $\mathrm{S}_{40}$ indicated that "In my opinion, concrete models lead student to think in certain ways. They prevent imagination and thinking."

The problems mentioned under the dimension of student perceptions include concrete models' making students confused, distracting their attention and perceived as a game. For example, $\mathrm{S}_{12}$ stated that "As students are still children during their elementary education, it will be quite difficult to draw students' attention while using concrete models. In the use of concrete models, it seems to be inevitable for students to show tendency to play."

Under the dimension of problems arising from curriculum and the system, the pre-service teachers mentioned that concrete models should not be used in elementary schools due to reasons such as the intensity of the curriculum, the examination system and the teachers' belief that the traditional way of teaching is easier. $\mathrm{S}_{9}$ indicated that "Use of concrete models may help students to understand difficult subjects. For example, algebraic expressions, volumes, concrete models can be used in teaching of many subjects. Yet, the education system in our country is not much suitable for this. The time is limited and classrooms are crowded; thus, classroom management can be difficult. As our examination system mostly requires students to solve problems, solving problem in the class can be more useful for students."

Some pre-service teachers; on the other hand, mentioned both positive and negative sides of concrete models and think that concrete models should be used from time to time, but not always. The opinions of these pre-service teachers are addressed under two dimensions as features of class and subjects and cost and physical adequacy. As for the dimension of features of class and subjects, the pre-service teachers stated that they could use them in teaching challenging subjects, some/suitable subjects, if physical conditions are adequate, concrete models are present at school, classrooms are not crowded and cost is reduced. They are also of the opinion that if concrete models are used in each class, they may lose their efficiency and without concrete models, students cannot proceed towards mathematical symbols. For example, $\mathrm{S}_{23}$ stated that "...They cannot be used to teach each subject, in each class. They should be used only for making students internalize the subject because when they are continuously used, then students get so accustomed to them that they cannot answer a question without using them." and $\mathrm{S}_{26}$ stated that "Use of concrete models may not be effective in some subjects. In some schools, the number of students in classes is too high. In such classrooms, if teachers want to teach with concrete models, they may realize that they are not very effective. Thus, they should not be used always."

\subsubsection{Pre-service Teachers Opinions about the Effect of Micro-teaching Practices with Concrete Models on Skills of Using Concrete Models}

The pre-service teachers were asked the question "Did the micro-teaching practices with concrete models have any impact on your skills of using concrete models?" The pre-service teachers' responses given to this question were presented in Table 3.

Table 3. Opinions about the effect on the skills of using concrete models

\begin{tabular}{|c|c|c|}
\hline Themes & Sub-themes & $\mathbf{f}$ \\
\hline \multirow{9}{*}{$\begin{array}{l}\text { Had effect. By micro-teaching practices with } \\
\text { concrete models.... }\end{array}$} & I found practice opportunities & 9 \\
\hline & I saw my shortcomings and corrected them & 9 \\
\hline & I saw my mistakes and corrected them & 8 \\
\hline & I found opportunity to develop myself & 7 \\
\hline & I gained some information/skills & 6 \\
\hline & I received feedback & 3 \\
\hline & I gained experience & 3 \\
\hline & I saw the problems that I can encounter while teaching in the class & 3 \\
\hline & I saw whether I am adequate or not & 3 \\
\hline
\end{tabular}


All of the pre-service teachers think that the micro-teaching practices with concrete models made positive contributions to their competency of using concrete models. When the pre-service teachers' opinions are examined, it is seen that through micro-teaching practices, they found practice opportunities about using concrete models, saw their shortcomings and corrected them, saw their mistakes and corrected them, developed themselves in terms of using concrete models, gained some information and skills, received feedbacks, gained experience in the use of concrete models, saw the problems that they could encounter while teaching with concrete models in the class and saw whether they are adequate or not in using concrete models. The pre-service teachers expressed their opinions as follows:

In this regard, $\mathrm{S}_{22}$ expressed her opinion about received feedbacks as follows: "The micro-teaching practices conducted with concrete models gave us some feedbacks about how we use the concrete models. By watching videos, we saw the mistakes we had committed in the use of concrete models and found opportunities to minimize such mistakes.". On the other hand $\mathrm{S}_{24}$ stated that "We have gained experience about how to teach any subject by using concrete models. We have found opportunities to talk about our mistakes while using concrete models and correct them...". With her statements "While conducting activities with base ten blocks, I got confused for a moment, I could not figure out how to model the subtraction operation. I recognized that I have some shortcomings in the use of concrete models." $\mathrm{S}_{16}$ indicated that she saw her shortcomings about using concrete models by micro-teaching practices.
$\mathrm{S}_{14}$ stated that he can gain skills of using concrete models with his expression "Teaching by using concrete models; in my opinion, requires enough information, skills and experience. Such information and skills can be gained through micro-teaching practices." On the other hand with her statement "We have seen whether we were successful in using concrete models while teaching in the class and whether we had some shortcomings in the use of them. " $\mathrm{S}_{34}$ and with her statement "...I have learned which concrete model to use and how to use it, for example, how to use the geometry board, symmetry mirror etc. in teaching different subjects." We have received feedbacks about the points in which we had some shortcomings." $\mathrm{S}_{5}$ indicated to receive feedbacks about using concrete models. $\mathrm{S}_{15}$ stated that "While conducting micro-teaching practices, teaching subjects with concrete models, we were able to see the problems that we could encounter. If there are mistakes we have committed, we can see them." Finally, with her following statement $\mathrm{S}_{27}$ indicated that by microteaching practices with concrete models he saw whether he is adequate or not "... When I watch the videos later, I can recognize whether I have been able to use concrete models appropriately; If I haven 't, I try to correct my mistakes."

\subsubsection{Pre-service Teachers Opinions about the Effect of Micro-teaching Practices with Concrete Models on the Teaching Skills}

The pre-service teachers were asked the question "Did the micro-teaching practices you conducted have some contributions to your teaching skills? How?" The pre-service teachers' responses given to this question were presented in Table 4.

Table 4. Opinions about the effect of the micro-teaching conducted through concrete models on teaching skills

\begin{tabular}{|c|c|c|}
\hline Theme & Sub-theme & $\mathrm{f}$ \\
\hline \multirow{2}{*}{ Feedback about classroom management } & Communication skill & 20 \\
\hline & Classroom/Time management & 7 \\
\hline \multirow{5}{*}{ Feedback about pedagogical knowledge } & Teaching at the level of students & 4 \\
\hline & Conveying the knowledge to students & 3 \\
\hline & Selecting words that can be understood by students & 3 \\
\hline & Seeing how to perform introduction to the lesson & 3 \\
\hline & Seeing whether the principles and methods of teaching have been used & 2 \\
\hline \multirow{2}{*}{ Feedback about pedagogical content knowledge } & Seeing whether the concepts and terms have been used properly & 10 \\
\hline & Seeing the skill of using concrete models & 9 \\
\hline \multirow{3}{*}{ Gaining experience } & Opportunity for personal development & 6 \\
\hline & Gaining experience in terms of using concrete models & 5 \\
\hline & Gaining teaching experience & 5 \\
\hline \multirow{6}{*}{ Self-evaluation } & Seeing one's own mistakes, errors & 16 \\
\hline & Seeing subjects in which they are inadequate & 13 \\
\hline & Seeing knowledge and skills they have & 12 \\
\hline & Seeing the lack of self-confidence & 10 \\
\hline & Self-criticism & 10 \\
\hline & Seeing one's self-efficacy & 9 \\
\hline \multirow{2}{*}{ Peer evaluation } & Seeing their peers' shortcomings, correcting themselves & 8 \\
\hline & Seeing their peers' shortcomings, giving feedback to peers & 7 \\
\hline
\end{tabular}


As can be seen in Table 4, all of the pre-service teachers stated that the micro-teaching practices had some positive effects on the development of their teaching skills. These effects are addressed under six dimensions that are feedback about classroom management, feedback about pedagogical knowledge, feedback about pedagogical content knowledge, gaining experience, self-evaluation and peer evaluation. Many of the pre-service teachers remarked that under the dimension of classroom management, they evaluated themselves in terms of communication skills, classroom/time management and received feedbacks about these issues. For example, $\mathrm{S}_{41}$ stated that "When I watched the videos, I realized that I looked at the board too much and made fewer eye-contacts with the students." Similar to this $\mathrm{S}_{33}$ emphasized "Delivery of a lesson requires self-expression, using gestures and mimics, using the tone of voice properly and establishing communication with students by getting them to participate in the lesson. When I watched the videos, I recognized that I had some shortcomings in these issues and had to develop my communication skills". In addition $\mathrm{S}_{10}$ expressed his opinions about time management with this statement "I recognized that I had not used the time effectively." On the other hand $\mathrm{S}_{39}$ mentioned classroom management by stating that "Through micro-teaching, I recognized that I could not manage the class well while teaching with concrete models."

The dimension of feedback about pedagogical knowledge includes teaching at the level of students, conveying knowledge to students, selecting the words that students can understand, seeing how to perform introduction to the lesson and seeing whether the principles and methods of teaching have been used. $\mathrm{S}_{3}$ expressed his opinion as follows "Through micro-teaching, the pre-service teacher can see how he/she behaves while teaching, how he/she has started the subject and whether he/she has drawn the interest of students."

The dimension of feedback about pedagogical content knowledge include seeing whether concepts and terms have been used properly and seeing the skill of using concrete models. For instance $\mathrm{S}_{7}$ stated that "I realized that I did not have enough information about the use of concrete models and as a result, that I had experienced problems while teaching through concrete models."

The dimension of gaining experience includes opportunity for personal development, gaining experience in terms of using concrete models, gaining teaching experience. $\mathrm{S}_{8}$ expressed her opinions "We have gained experience about the use of concrete models. " On the other hand $\mathrm{S}_{9}$ indicated gaining teaching experience by stating "...for many of us it was the first teaching experience" and $\mathrm{S}_{38}$ by stating "...This application made me first time think as a teacher. I saw what kind of teacher I would be, though to a small extent."

The dimension of self-evaluation is classified as seeing one's own mistakes and errors, seeing subjects in which they are inadequate, seeing knowledge and skills they have, performing self-criticism, seeing one's self-confidence. One of the pre-service mathematics teachers $\mathrm{S}_{23}$ thinks that "In this way, we have seen our own mistakes. We have learned some lessons from our mistakes. We have seen where we committed the most mistakes and how to correct these mistakes." and $\mathrm{S}_{5}$ stated that "We can see our shortcomings through the micro-teaching practices. For example, when I watched the video I realized that I had got too much exited and could not control the class." Another pre-service teachers $\mathrm{S}_{14}$ mentioned self-confidence by statement "Through micro-teaching, I have gained my self-confidence because I was afraid of teaching at the board. When I watched the videos, I thought that how well I had presented the subject."

In the dimension of peer evaluation, they mentioned seeing the shortcomings of their peers, correcting themselves and giving feedbacks to peers and correcting them. For instance, with her statements "When I watched my peers, I realized what kind of presentation styles I should adopt.", $\mathrm{S}_{2}$ indicated that she corrected her shortcomings by feedbacks. $\mathrm{S}_{16}$ argued that they give feedbacks to peers by stating that "We watched our peers' videos and we saw their shortcomings, made comments on their performances and said how they could be made better."

\section{Conclusions}

The purpose of the current study is to investigate the effect of micro-teaching practices with concrete models on the pre-service teachers' self-efficacy beliefs about using concrete models and to determine the opinions of the pre-service teachers about this issue. In light of the findings of the current study, it can be argued that the micro-teaching practices with concrete models had positive effects on the pre-service teachers' self-efficacy beliefs about using concrete models. The qualitative findings obtained from the pre-service teachers also confirmed that the micro-teaching practices conducted with concrete models contributed to the development of the pre-service teachers' self-efficacy about using concrete models. Many other studies have also revealed that micro-teaching practices have positive effects on teaching self-efficacy [65-69]. Mergler and Tangen [68] stated that micro-teaching enhances pre-service teachers' sense of self-efficacy in teaching. On the other hand Arsal [65] also found that micro-teaching had a positive impact on developing pre-service teachers' sense of self-efficacy in teaching.

Given that one of the important sources of self-efficacy is direct experiences, this finding can be explained by the fact that micro-teaching practices provide environments for pre-service teachers to live direct experiences of using concrete models. In micro-teaching, the pre-service teacher 
can watch his/her own performance on video after the presentation and see his/her strengths, and this might increase his/her self-efficacy beliefs [69]. Another source of self-efficacy is indirect experiences [48]. In micro-teaching, the pre-service teacher watches his/her peers' concrete model using performances and may think that he/she can also do the same things. This may increase their self-efficacy beliefs about using concrete models. Mergler and Tangen [68] also stated that pre-service teachers can engage in both vicarious and mastery learning experiences with micro-teaching practices. Positive feedbacks taken from the instructor and peers may be effective in increasing the pre-service teachers' self-efficacy for using concrete models. Another source of self-efficacy beliefs is affective and psychological states [48]. By creating classroom environments in which pre-service teachers feel psychologically and physically comfortable, the micro-teaching technique allows the pre-service teachers to reduce their anxiety and stress and cope with their excitement. This might have positively affected the pre-service teachers' self-efficacy for using concrete models. Given that teachers with high self-efficacy beliefs are more persistent when they face an obstacle, the pre-service teachers can be claimed to invest more efforts to overcome the difficulties [31-32], they will be confronted with while using concrete models in their classes when they become teachers.

When the pre-service teachers' opinions about the use of concrete models in elementary schools were examined, it was found that they mentioned the contributions of concrete models to teaching and learning such as increasing permanent learning, reification of abstract concepts, facilitation of learning and understanding, provision of visualization, conceptual learning, visualization in the mind/spatial thinking, effective teaching and reinforcement of subjects. When the relevant literature is reviewed, it is seen that many studies have shown that concrete models embody abstract mathematical concepts $[4,5]$, facilitate the understanding of mathematical concepts [5-9], realize conceptual learning [10] and increase permanent learning $[9,11,12]$. Pişkin [29] reported that the pre-service teachers are of the opinion that concrete models make positive contributions to students' learning and teaching process. Aydoğdu-İskenderoğlu and Taşkın [74] also noted that the pre-service teachers think that concrete materials can have some positive influences such as facilitating the delivery of a lesson and presentation of a subject, helping students understand a subject better, reifying concepts, drawing students' attention, making meaningful learning possible and increasing the retention of a lesson. Moreover, it was also mentioned that concrete models are useful in terms of drawing the interest/attention of students and making the lesson more enjoyable. This concurs with the studies reporting that concrete models contribute to the development of positive attitudes in students [13-16]. Another positive aspect of concrete models was stated to be their allowing more effective use of time. This is parallel to the finding reported by Kıyıc1, Erdoğmuş and Sevinç [75] stated that the pre-service teachers think that concrete materials shorten instruction time. As a result of the micro-teaching practices, many of the pre-service teachers remarked that concrete models should be used in math classes, which is an important finding. This is believed to be a result of performing micro-teaching practices through which the pre-service teachers gained direct experiences about the use of concrete models. Indeed, Çakıroğlu and Yıldız [34] reported that the pre-service teachers who used materials during their education would be more willing to use materials in their classes in the future when they become teachers.

On the other hand, there are some pre-service teachers thinking that concrete models should not be used in elementary schools as they are time-consuming, make the classroom management difficult, become monotonous over time, hinder imagination and thinking, can make students feel confused, can distract their attention, can be seen as a game, the curriculum is too intense, teaching through traditional approaches is easier and the examination system is not suitable because it requires solving problems rather than using materials in the class. Pişkin [29] stated that the pre-service teachers believe that the greatest difficulty they can experience while teaching mathematical concepts by using concrete models is classroom management. For math teachers to be effective, it is of great importance for them to manage the learning environment while using concrete models [27]. Gökmen, Budak and Ertekin [76] noted that math teachers avoid using concrete materials due to reasons such as families' expectations about the exam, materials' being not economical, teachers' lack of pedagogical content knowledge about the use of materials, difficulty of organizing materials, difficulty of managing classroom when materials are used, perceptions of concrete materials and limited time. These researches findings are parallel to findings.

Some pre-service teachers; on the other hand, stated that they could use concrete models in some situations; for example, while teaching challenging subjects, some specific/suitable subjects, when the physical conditions at school are adequate, when the classroom is not crowded, when there are enough concrete materials and when the cost of using concrete models is reduced. These statements show that the pre-service teachers do not support the continuous use of concrete materials. Çelik [77] also reported that many factors such as objectives of the instruction, classroom management, student characteristics, characteristics of the instructional setting, characteristics of tools and equipment and restrictions (e.g. time, budget) affect the selection of teaching materials.

All of the pre-service teachers in the current study are of the opinion that the micro-teaching practices with concrete models had positive effects on their skills of using concrete 
models. The pre-service teachers' opinions in this regard revealed that they were able to find opportunities; through the micro-teaching applications, to see how effective they are in using concrete models, to see what their mistakes and shortcomings are and correct them, to develop themselves in the use of concrete models, to gain information and skill, to receive feedbacks, to gain experience about the use of concrete models, to see the problems to be experienced while teaching with concrete models and to see whether they are competent or not in using concrete models. Şen [78] argues that pre-service teachers gain experience and increase the number of teaching methods and materials they use as a result of micro-teaching practices.

When the pre-service teachers' opinions about the effect of the micro-teaching practices on the skill of teaching are examined, it is seen that many of them think that these micro-teaching practices had positive effects on the skills of teaching. He and Yan [79] also stated that micro-teaching was a useful tool for the pre-service teachers' professional development. Within the context of classroom management dimension, the pre-service teachers stated that they were able to evaluate themselves in terms of communication, time management, classroom management and received feedbacks. These findings concur with the findings of many other studies in the literature. Micro-teaching practice is a valuable tool to help students develop communication skills [80]. Sevim [81] reported that micro-teaching practices had positive effects on the pre-service teachers' classroom management skills and developed particularly their non-verbal communication skills. In the study by Savaş [56], the pre-service teachers stated that micro-teaching had developed their classroom management and materials design, board using and time management skills. On the other hand Kılıç [62] stated that micro- teaching practices have positive effects on subject area, planning, teaching process, classroom management, communication, and evaluation. Atav, Kunduz and Seçken [61] noted that micro-teaching practices made positive contributions to the pre-service teachers' classroom management skills and helped them to develop their both verbal and non-verbal communication skills.

In the current study, the pre-service teachers stated that by means of micro-teaching practices, they can receive feedbacks about their pedagogical knowledge such as whether they can teach at the level of students, they can convey information to students, can select the worlds that can be understood by students, how to make introduction to the lesson and whether they use the principles and methods of teaching and feedbacks about their pedagogical content knowledge such as whether they can use concepts and terms properly and can use concrete models. These findings are parallel to the findings reported by Peker [57] stating that through micro-teaching, pre-service teachers gain experience of real teaching, can see their shortcomings in terms of content knowledge and content education, can see their shortcoming in classroom management, can learn how to prepare better lesson plans. Moreover, through micro-teaching applications, the pre-service teachers stated that they were able to see their mistakes and shortcomings and subjects in which they were inadequate, see which skills and knowledge they had and conducted self-criticisms. Sevim [81] found that micro-teaching applications provide pre-service teachers with opportunities to see their shortcomings, to evaluate themselves and to take responsibility in learning.

The dimension of gaining experience includes opportunities for personal development, gaining experience in terms of using concrete models and gaining teaching experience. One of the most important benefits of micro-teaching applications is that pre-service teachers gain experience [35, 78, 79]. In addition, their doing some activities related to use of concrete models help them gain experience about how to use these models in the future when they become teachers. Teachers need to know how to use concrete models effectively, when, why and how to use them [17]. Such micro-teaching applications help pre-service teachers to acquire such experiences and knowledge.

Within the context of self-evaluation dimension, the pre-service teachers stated that they were able to see their mistakes and shortcomings, the subjects in which they were inadequate, knowledge and skills they possessed and their self-efficacy and then made self-criticism. As the micro-teaching process was video-recorded, pre-service teachers could conduct self-evaluation after their presentation [37, 69]. Furthermore, they stated that they had seen whether they had self-confidence during their presentations and developed their self-confidence. Many other studies have also shown that micro-teaching applications increased pre-service teachers' self-confidence [35, 51, 57].

Within the context of peer evaluation dimension, the pre-service teachers stated that they were able to correct themselves by seeing their peers' shortcomings and gave them feedbacks. Through micro-teaching applications, individuals can evaluate both themselves and their peers [80].

As a conclusion, incorporating micro-teaching practices into teacher training programs is believed to make contributions to the attempts made to train more qualified teachers. Micro-teaching practices conducted with concrete models can help pre-service teachers develop themselves in terms of classroom management, time management and get rid of negative opinions related physical conditions and student perceptions. Therefore, such applications can be suggested to be conducted in the courses of "School Experience" and "Teaching Practicum". Moreover, such applications can be conducted by using concrete models to be designed by pre-service teachers themselves. Same applications can be conducted for teachers. In this way, teachers can also see their mistakes 
and shortcomings in the use of concrete models.

\section{Acknowledgements}

This article is supported under the Aksaray University Scientific Research Project (Project Number: BAP 2017-022) and presented in Academic Conference on Education, Teaching and e-Learning in 11-14 August 2017 in Prague.

\section{REFERENCES}

[1] NCTM Principles and standards for school mathematics. Reston, VA: NCTM Publications. (2000).

[2] Ministry of National Education. İlköğretim matematik dersi 6-8. siniflar ögretim program 1 [Elementary mathematics (6th -8th grade) curriculum]. Ankara: Author, 2005.

[3] Boggan, M., Harper, S. \& Whitmire, A. Using manipulatives to teach elementary mathematics. Journal of Instructional Pedagogies, Vol. 3, 2010.

[4] Bellinio, J. L. Multi-Sensory Manipulatives in Mathematics: Linking the Abstract to the Concrete Yale-New Haven Teachers Institute. In http://www.yale.edu/ynhti/curriculum/units/2001/6/01.06.1 2.x.html (15.02.2016), 2012.

[5] Moyer, P.S. Are we having fun yet? How teachers use manipulatives to teach mathematics. Educational Studies in Mathematics, Vol.47, 175-197, 2001.

[6] Allen, C. An action based research study on how using manipulatives will increase students' achievement in mathematics. Online Submission. Retrieved from http://files.eric.ed.gov/fulltext/ED499956.pdf. (2007).

[7] Izsak, A. Students' coordination of knowledge when learning to model physical situations. Cognition and Instruction, Vol. 22, No.1, 81-128, 2004.

[8] Kennedy, L. M., \& Tipps, S. Guiding children's learning of mathematics. Belmont, Ca: Wadsworth Pub. Co., 1994.

[9] Suh, J., \& Moyer-Packenham, P. Developing students' representational fluency using virtual and physical algebra balances. Journal of Computers in Mathematics and Science Teaching, Vol.26, No.2, 155-173, 2007.

[10] Dienes, Z. A Theory of mathematics-learning. In F. J. Crosswhite, et al. (Eds.). (1973). Teaching mathematic: Psychology foundations. Worthington, Ohio, Charles A. Jones Pub. Co. Dienes. (1967).

[11] Cass, M., Cates, D., Smith, M., \& Jackson, C. Effects of manipulative instruction on solving area and perimeter problems by students with learning disabilities. Learning Disabilities Research \& Practice, Vol.18, No.2, 112-12, 2003.

[12] Martin, T., \& Schwartz, D. L. Physically distributed learning: Adapting and reinterpreting physical environments in the development of fraction concepts. Cognitive Science, Vol.
29, No. 4, 587-625, 2005.

[13] Fuson, K. C., \& Briars, D. J. Using a base-ten blocks learning/teaching approach for first- and second-grade place-value and multidigit addition and subtraction. Journal for Research in Mathematics Education, Vol.21, No.3, 180-206, 1990.

[14] Johnson, K. A. Manipulatives allow everyone to learn mathematics. Contemporary Education, Vol.65, No.1, 10-11, 1993.

[15] Martelly, D., I. Effects of using manipulative materials to teach remedial algebra to community college students on achievement and attitudes towards mathematics. Unpublished doctoral dissertation, Florida International University, Miami, 1998.

[16] Sowell, E. Effects of manipulative materials in mathematics instruction. Journal for Research in Mathematics Education, Vol.20, 498-505, 1989.

[17] Kelly, A. C. Using manipulatives in mathematical problem solving: a performance- based analysis. The Montana Mathematics Enthusiast, Vol.3, No.2, 184- 193, 2006.

[18] Aburime, F. i. How manipulatives affect the mathematics achievement of students in Nigerian schools. Educational Research Quarterly, Vol.31, No.1, 3-15, 2007.

[19] Ball, D. Magical Hopes: Manipulatives and the reform of math education. American educator: The Professional Journal of the American Federation of Teachers, Vol.16, No.2, 14-18, 1992.

[20] Bayram, S. The Effect of Instruction with Concrete Models on Eighth Grade Students' Geometry Achievement and Attitudes Toward Geometry, Master's Thesis, Middle East Technical University, Ankara, Turkey, 2004.

[21] Kilıç, H., Tunç-Pekkan, Z. \& Karatoprak, R. Materyal kullanımının matematiksel düsünme becerisine etkisi. Eğitimde Kuram ve Uygulama, Vol.9, No.4, 544-556, 2013.

[22] Manches, A., O’Malley, C., \& Benford, S. The role of physical representations in solving number problems: A comparison of young children's use of physical and virtual materials. Computers \& Education, Vol.54, No.3, 622-640, 2010.

[23] Martelly, D., I. Effects of using manipulative materials to teach remedial algebra to community college students on achievement and attitudes towards mathematics. Unpublished doctoral dissertation, Florida International University, Miami, 1998.

[24] Swan, P., \& Marshall, L. Revisiting mathematics manipulative materials. Australian Primary Mathematics Classroom, Vol.15, No.2, 13-19, 2010.

[25] Thompson, P. Concrete materials and teaching for mathematical understanding. Arithmetic Teacher, Vol.41, No.9, 556-558, 1994

[26] Stein, M. K. \& Bovalino, J. W. Manipulatives: One piece of the puzzle. Mathematics Teaching in the Middle School, Vol.6, No.9, 356-359, 2001.

[27] Marshall, L., \& Swan, P. (2008). Exploring the Use of Mathematics Manipulative Materials: Is It What We Think It Is?. Proceedings of the EDU-COM 2008 Sustainability in 
Higher Education: Directions for Change. 338-350, 2008.

[28] Kelly, A. C. Using manipulatives in mathematical problem solving: A performance- based analysis. The Montana Mathematics Enthusiast, Vol.3, No.2, 184- 193, 2006.

[29] Pişkin, M. Investigation of pre-service elementary mathematics teachers' self-efficacy beliefs about using concrete models in teaching mathematics. Master's Thesis, Middle East Technical University, Ankara, Turkey, 2010.

[30] Schunk, D. Öğrenme Teorileri: Eğitimsel Bir Bakışla: (Translated from Fifth Edition). (Trans. Ed. Muzaffer Şahin). Ankara: Nobel Yayıncilık, 2009.

[31] Ross, J.A. Strategies for enhancing teachers' beliefs in their effectiveness: research on a school improvement hypothesis. Teachers College Record, Vol.97, No.2, 227-251, 1995.

[32] Woolfolk Hoy, A. Self-efficacy in college teaching. Essays on Teaching Excellence toward the Best in the Academy. Vol.15, No.8, 2003.

[33] Yetkin- Özdemir, E. Sınıf öğretmeni adaylarının matematik öğretiminde materyal kullanımına ilişskin bilişsel süreçleri. Hacettepe Üniversitesi Eğitim Fakültesi Dergisi, Vol.35, 362-373, 2008.

[34] Çakıroğlu, E. \& Yıldız, B. T. Turkish preservice teachers' views about manipulative use in mathematics education. In C. S. Sunal, \& M. Kagendo (Eds.), The enterprise of education (pp. 275-289). Information Age Publishing Inc. (2007).

[35] Amobi, F. A. Preservice teachers' reflectivity on the sequence and consequences of teaching actions in a microteaching experience. Teacher Education Quarterly, Vol.32, No.1, 115-130, 2005.

[36] Allen, D. W. Microteaching: A personal review. British Journal of Teacher Education, Vol. 6, No.2, 147-151, 1980.

[37] Akkus, H., \& Üner, S. The effect of microteaching on pre-service chemistry teachers' teaching experiences. Çukurova University. Faculty of Education Journal, Vol.46, No.1, 202, 2017

[38] Van de Walle, J. A. (2007). Elementary and middle school mathematics: Teaching developmentally (6th ed.). Boston, MA: Pearson /Allyn and Bacon.

[39] Willis, J., \& Browning, S. (2013, March). Introduction to Mathematics Manipulatives: Preservice Teachers Create Digital Stories Illustrating Types and Application of Manipulatives. In Society for Information Technology \& Teacher Education International Conference (pp. 1795-1815). Association for the Advancement of Computing in Education (AACE).

[40] Uttal, D. H., Scudder, K. V., \& DeLoache, J. S. Manipulatives as symbols: A new perspective on the use of concrete objects to teach mathematics. Journal of Applied Developmental Psychology, Vol.18, 37-54, 1997.

[41] National Council of Teachers of Mathematics. (1989). Curriculum and evaluation standards for school mathematics. Reston, VA: NCTM.

[42] Moore, N. D. Alternative Strategies for Teaching Mathematics, 58. Retrieved from http://digitalcommons.brockport.edu/ehd_theses. (2012)
[43] Kamina, P. \& Iyer, Nithya N., "From Concrete to Abstract: Teaching for Transfer of Learning when Using Manipulatives" (2009). NERA Conference Proceedings 2009. 6. http://digitalcommons.uconn.edu/nera_2009/6.

[44] Bakkaloğlu, E. Preservice elementary mathematics teachers' efficacy beliefs about using manipulatives in teaching mathematics. Unpublished master's thesis, Middle East Technical University, Ankara, 2007.

[45] Bandura, A. Social foundations of thought and action. Englewood Cliffs, NJ: Prentice Halls, 1986.

[46] Aydoğdu-İskenderoğlu. T, Türk, Y., \& İskenderoğlu, M. İlköğretim matematik öğretmeni adaylarının somut materyalleri tanıma-kullanma durumları ve matematik öğretiminde kullanmalarına yönelik öz-yeterlikleri. Mehmet Akif Ersoy Üniversitesi Eğitim Fakültesi Dergisi, Vol.1, No.39, 1-15, 2016.

[47] Bandura, A. Gauging the relationship between self-efficacy judgment and action. Cognitive Therapy and Research, 4, 263-268, 1980.

[48] Bandura, A. Self-efficacy: The exercise of control. New York: Freeman, 1997.

[49] Hazır-Bıkmaz, F. Özyeterlik inançları. In Yıldız Kuzgun \& Deniz Deryakulu (Ed.), Eğitimde bireysel farklılıklar. (pp.291-310). Ankara: Nobel Publishing (2nd Edition), 2006.

[50] Mohan, R. Teacher education, New Delhi: PHI, 2011.

[51] Benton-Kupper, J.B. The microteaching experience: Student perspectives. Education, Vol.121, No.4, 830-835, 2001.

[52] Kpanja, E. A Study of the effects of video tape recording in microteaching training, British Journal of Educational Technology, 32(4), 483-486. (2001).

[53] Sherin, M. G. New perspectives on the role of video in teacher education. In J. Brophy (Ed.), Using video in teacher education (pp. 1-28). New York: Elsevier, 2004.

[54] Kavas, G. Video destekli web tabanlı değerlendirme sisteminin mikroöğretim uygulamaları üzerine etkileri: bilgisayar ögretmeni adayları örneği. Unpublished master thesis, Marmara University, 2009.

[55] Greg, C. L. \& Cheng-Chih, W. Enhancing the teaching experience of pre-service teachers through the use of videos in web-based computer-mediated communication (CMC). Innovations in Education and Teaching International. Vol. 43, No. 4. ISSN 1470-3297 (print)/ISSN 1470-3300 (online)/06/040369- 12@ 2006 Taylor \& Francis DOI: 10.1080/14703290600973836. (2006).

[56] Savaş, P. Micro-teaching videos in EFL teacher education methodology courses: Tools to enhance English proficiency and teaching skills among trainees. Procedia-Social and Behavioral Sciences, Vol.55, 730-738, 2012.

[57] Peker, M. Genişletilmiş mikro öğretim yaşantıları hakkında matematik öğretmeni adaylarının görüşleri. Türk Eğitim Bilimleri Dergisi. Bahar 2009, Vol.7, No.2, 353-376, 2009.

[58] Cheng, J. Learning to attend to precision: the impact of micro-teaching guided by expert secondary mathematics teachers on pre-service teachers' teaching practice. ZDM, Vol. 49, No.2, 279-289, 2017. 
[59] Elliot, J. A microteaching experiment at MEDUNSA. South African Medical Journal, Vol.62, 868-870, 1982.

[60] Fernandez, M. L. Learning through microteaching lesson study in teacher preparation. Action in Teacher Education, Vol.26, 37-47, 2005.

[61] Atav, E., Kunduz, N., \& Seçken, N. Biyoloji eğitiminde mikro öğretim uygulamalarına dair öğretmen adaylarının görüşleri pre-service teachers' views about micro teaching practices in Biology education. Hacettepe University Journal of Education, Vol. 29, No.4, 01-15, 2014.

[62] Kilıç, A. Learner-centered micro teaching in teacher education. International Journal of Instruction, Vol.3, No.1, 77-100, 2010.

[63] Küçükoğlu, A., Köse, E., Taşgın, A., Yılmaz, B. Y., \& Karademir, Ş. Mikro öğretim uygulamasının öğretim becerilerine etkisine ilişkin öğretmen adayı görüşleri. Eğitim Bilimleri Araştırmaları Dergisi, Vol.2, No.2, 19-32, 2012.

[64] Shaw, D. Accomplished teaching: Using video recorded Micro-teaching discourse to build candidate teaching competencies. Journal of Interactive Learning Research, Vol.28, No.2, 161-180, 2017.

[65] Arsal, Z. Microteaching and pre-service teachers' sense of self-efficacy in teaching, European Journal of Teacher Education, Vol. 37, No. 4, 453-464, 2014 DOI:10.1080/02619768.2014.912627.

[66] Bilen, K. Effect of micro teaching technique on teacher candidates' beliefs regarding mathematics teaching. Procedia-Social and Behavioral Sciences, Vol.174, 609-616, 2015.

[67] Cinici, A. Pre-service teachers' science teaching self-efficacy beliefs: the influence of a collaborative peer microteaching program. Mentoring \& Tutoring: Partnership in Learning, Vol.24, No.3, 228-249, 2016.

[68] Mergler, A. G. \& D. Tangen. Using microteaching to enhance teacher efficacy in pre-service teachers. Teaching Education Vol.21, No.2, 199-210, 2010.

[69] Tok, Ş. Mikro öğretim yönteminin öğretmen adaylarının özyeterlik inançlarına ve mesleğe yönelik tutumlarına etkisi. Milli Eğitim Dergisi, Vol.45, No.212, 5-25, 2016.

[70] Creswell \& Clark. Karma yöntem araştırmaları tasarımı ve yürütülmesi. (Translated from $2^{\text {nd }}$ Edition) (Trans. Ed. Y. Dede \& S. B. Demir). Ankara: Anı Yayıncılık. 2014.

[71] Patton, M. Q. Qualitative research and evaluation methods (3rd ed.). Thousand Oaks, CA: Sage. (2002).

[72] Yıldırım, A., \& Şimşek, H. Sosyal Bilimlerde Nitel Araştırma Yöntemleri, Ankara: Seçkin Yayıncılık, 2004.

[73] Miles, M. B., \& Huberman, A. M. Qualitative data analysis: An expanded source book. California, CA: Sage, 1994.

[74] Aydoğdu-İskenderoğlu T. \& Taşkın D. İlköğretim matematik öğretmeni adaylarının özel öğretim yöntemleri dersinde somut materyalleri seçme ve kullanma nedenleri. Dicle Üniversitesi Ziya Gökalp Eğitim Fakültesi Dergisi, Vol.25, 215-237, 2015

[75] Kıyıcı, G., Erdoğmuş, E. \& Sevinç, Ö.S. Sınıf ortamında materyal kullanımının eğitim öğretime katkısı ile ilgili öğretmen adaylarının görüşleri. The Proceedings of 7 th Educational Technology Conference, Near East University, International North Cyprus, 2007.

[76] Gökmen, A., Budak, A. \& Ertekin, E. İlköğretim ögretmenlerinin matematik öğretiminde somut materyal kullanmaya yönelik inançları ve sonuç beklentileri. Kastamonu Eğitim Dergisi, Vol.24, No.3, 859-874, 2015.

[77] Celik, L. Öğretim mataryallerinin hazırlanması ve seçimi. Özcan Demirel and Eralp Altun (Ed). Öğretim teknolojileri ve materyal tasarımı. Ankara: Pegem A Yayıncılık, 2010.

[78] Şen, A. İ. A Study on the effectiveness of peer Microteaching in a Teacher education program, Education and Science, Vol.34, No.151, 165-174, 2009.

[79] He, C., \& Yan, C. Exploring authenticity of microteaching in pre-service teacher education programs. Teaching Education, Vol. 22, No. 3, 291-302, 2011. http://dx.doi.org/10.1080/10476210.2011.590588

[80] Popovich, N. G., \& Katz, N. L. A microteaching exercise to develop performance-based abilities in pharmacy students. American Journal of Pharmaceutical Education, Vol.73, No.4, 73, 2009.

[81] Sevim, S. Mikro-öğretim uygulamasının öğretmen adayları gözüyle değerlendirilmesi. Dicle Üniversitesi Ziya Gökalp Eğitim Fakültesi Dergisi, Vol.21, 303-313, 2013. 